University of New Hampshire

University of New Hampshire Scholars' Repository

$1-2002$

\title{
Spankers and Nonspankers: Where They Get Information on Spanking
}

Wendy A. Walsh

University of New Hampshire - Main Campus, wendy.walsh@unh.edu

Follow this and additional works at: https://scholars.unh.edu/soc_facpub

Part of the Family, Life Course, and Society Commons, and the Psychology Commons

\section{Recommended Citation}

Walsh, W. (2002), Spankers and Nonspankers: Where They Get Information on Spanking. Family Relations, 51: 81-88. doi: 10.1111/j.1741-3729.2002.00081.x

This Article is brought to you for free and open access by the Sociology at University of New Hampshire Scholars' Repository. It has been accepted for inclusion in Sociology Scholarship by an authorized administrator of University of New Hampshire Scholars' Repository. For more information, please contact Scholarly.Communication@unh.edu. 


\title{
Spankers and Nonspankers: Where They Get Information on Spanking*
}

\begin{abstract}
Wendy Walsh**
Because spanking is common, puts children at risk for harmful side effects, and is ineffective as a positive behavior management tool, it is important to identify the kind of advice families receive about the appropriateness of spanking. Using the health belief model, I examined spankers and nonspankers on the spanking messages they received from eight sources of discipline information and how important they perceived these messages to be. Data from telephone interviews with 998 mothers with children aged 2 to 14 years showed that 33\% of mothers rated advice from workshops, pediatricians, newspapers and magazines, and books as "very important." Less than $15 \%$ rated parents and relatives and friends as such. Spankers perceived sources as recommending spanking, whereas nonspankers perceived sources as opposing spanking. Mothers were more likely to spank when they perceived more intense messages to spank, less intense messages opposing spanking, had younger children, and were of lower socioeconomic status.
\end{abstract}

$\mathrm{W}$ hat we read and learn from our environment influences behavior. The messages we perceive help us to determine what is normative or expected behavior. For example, public smoking was once culturally accepted and not questioned. Once the link between smoking and negative health effects was emphasized, smoking was redefined as harmful behavior, and legal controls were supported (Ferraro, 1990). Similarly, corporal punishment was once more culturally accepted than today. Because parenting attitudes and beliefs are formed in part by interaction with those in our social context and what we read, this study examines the sorts of advice families receive about the appropriateness of spanking and the importance of information sources.

\section{Spanking Prevalence}

Corporal punishment is defined as "the use of physical force with the intention of causing a child to experience pain, but not injury, for purposes of correction or control of the child's behavior" (Straus, 1994, p. 4). Six types of corporal punishment include slaps on the hand or leg, spanking on the buttocks, pinching, shaking, hitting on the buttocks with a belt or paddle, and slapping in the face (Straus \& Stewart, 1999). Spanking is common; approximately $67 \%$ of all parents report using some type of corporal punishment (Straus). This figure is misleading, however, because the use of corporal punishment is strongly dependent on the age of the child. For example, spanking on bottom with a hand is a common type of corporal punishment with $72 \%$ of parents of 2- to 4 -year-olds, $71 \%$ of parents of 5- to 8year-olds, $43 \%$ of parents of 9- to 12-year-olds, and $14 \%$ of parents of 13- to 17-year-olds using this type of corporal punishment (Straus \& Stewart).

*An earlier version of this article was presented at the Eastern Sociological Society Conference in Philadelphia, PA, March 1998. This research was from a thesis submitted to the Graduate School at the University of New Hampshire as part of the requirements for a Master of Science in Family Studies. Acknowledgements go to the members of the Family Violence Seminar for helpful comments on an earlier draft.

**Department of Sociology, University of New Hampshire, Horton Social Science Center, Durham, NH 03824

Key Words: corporal punishment, discipline, parenting, physical punishment, spanking.

(Family Relations, 2002, 51, 81-88)

\section{Characteristics Associated With Spanking}

Some adults spank more than others. The characteristics associated with spanking are the age of the child, age and gender of the parent, socioeconomic status, circumstances, and cultural norms. Younger parents are more likely to use corporal punishment than older parents (Giles-Sims, Straus, \& Sugarman, 1995; Straus \& Stewart, 1999; Wolfner \& Gelles, 1993). Mothers use corporal punishment more frequently than fathers, although the relative difference is small when time spent with the child is considered (Dietz, 2000; Wolfner \& Gelles). Research on the relationship between socioeconomic status and the use of corporal punishment is inconclusive (Dietz; Giles-Simes et al.; Straus, 1994; Wolfner \& Gelles). Parents who were hit as children are more likely to hit their children (Bryan \& Freed, 1982; Graziano \& Namaste, 1990; Rodriquez \& Sutherland, 1999; Straus).

Not only does a parent's past history with corporal punishment influence his or her own use of it, but also cultural and subcultural norms may influence the use of spanking. For example, Greven (1991) proposed that we have perceptual blinders to corporal punishment because nearly everyone has experienced it. Perceptual blinders may be more prevalent in some geographic locations. For example, research on regional differences on attitudes and use of corporal punishment has consistently found more support and use of it in the South than in other regions (Giles-Sims et al., 1995; Straus \& Mathur, 1996; Straus \& Stewart, 1999).

\section{Consequences of Spanking}

A growing body of literature on spanking has focused on the potential harmful effects of corporal punishment and its ineffectiveness as a child behavior management tool. Some of the potential harmful effects of frequent and severe spankings include subsequent antisocial behavior of children (Grusec \& Goodnow, 1994; McCord, 1991; Straus, Sugarman, \& GilesSims, 1997). Some research indicates that the effects are small and vary by age of child and ethnicity (Deater-Deckard, Dodge, Bates, \& Pettit, 1996; Larzelere, 1996). The excessive use of corporal punishment has been associated with a number of adult social and psychological problems, including physical aggression, delinquency, and depression (Foglia, 1997; Straus, 1994; Swinford, Demaris, Cernkovick, \& Giordano, 2000). In addition, physical punishments give children pain and may teach them it is all right to inflict pain on others (McCord, 1996). 
Research also indicates that spankings may work against what parents are trying to achieve. Results show that using corporal punishment leads to greater incidences of child aggression and maladaptive behaviors (Grusec \& Goodnow, 1994; Patterson \& Narrett, 1990; Strassberg, Dogde, Pettit, \& Bates, 1994). Research also indicates that abusive parents spank their children more often than nonabusive parents and that excessive spanking may be a risk factor for child abuse (Barber, 1992; Holden \& Ritchie, 1991; Kadushin \& Martin, 1981; Oldershaw, Walters, \& Hall, 1989; Whipple \& Richey, 1997; Whipple \& Webster-Stratton, 1991). Therefore, relying on spanking may increase the potential for use of frequent and severe physical punishment.

Paralleling the increase in knowledge about consequences of spanking, approval of corporal punishment has decreased from 94\% in 1968 to 68\% in 1994 (Straus \& Mathur, 1996), and reported use of corporal punishment has decreased from $64 \%$ in 1988 to $53 \%$ in 1992 (Daro \& Gelles, 1992). Nevertheless, 94\% of parents of 3- to 4-year-olds still report using corporal punishment (Straus \& Stewart, 1999). Thus, it is important to ask about the kind of advice families receive regarding the appropriateness of spanking.

\section{Spanking Messages and Advice}

Information about the appropriateness of spanking may be informal, such as comments from friends and relatives, or formal, such as information provided by professionals. Although parents seem to want information about child discipline, it is not clear where and what kind of information parents typically receive (Riley, Meinhardt, Nelson, Salisbury, \& Winnett, 1991; Thompson, 1994). For example, a national study found 4 out of 10 parents wanted discipline information from health professionals, yet only $23 \%$ of parents reported discussing discipline with their child's pediatrician (Young, Davis, \& Schoen, 1996).

In addition to the spanking advice parents receive, we know little about how consistent or strong such messages are. Perhaps the discipline message from friends and relatives creates confusion or conflict if the advice is contradictory to one's own beliefs or if information sources do not send similar messages (Edwards, 1995; Powell, 1979; Small \& Eastman, 1991). The effects of discipline messages also may depend on how valued the source is and what kind of messages are provided. For example, Small and Eastman showed that, depending on the message, an information source could serve as a support or stressor. They found that when the source is valued and gives needed advice, that source is perceived as supportive. If the source has different views on child rearing from those of the parent, then that source could be a stressor. Depending on any sanctions imposed, such as parents criticizing how their child parents or a social worker removing a child from the home, the advice may have differential effects. Therefore, the current study examined spanking messages relative to the importance of the information source.

\section{Theoretical Framework}

Building on the principle that our attitudes and behaviors are formed, in part, by the environment, the health belief model (Ferraro, 1990) incorporates how community norms and opinions about the negative consequences of a behavior affect an individual's willingness to change a behavior. This framework has been used to examine the influence of community norms on smoking cessation, seatbelt safety, alcohol use, and dietary fat intake. The health belief model looks beyond the individual to consider how macrolevel norms and environmental supports encourage individuals to change behaviors (Portnoy, Anderson, \& Erikson, 1989). Environmental supports include social support, availability and accessibility of services, and the mass media.

The health belief model examines how the perception of what is standard or acceptable behavior and public opinion influences an individual's behavior, positing that positive behavior change is enhanced when support networks and community structure reinforce such change. For example, the degree of support for smoking in a community was an important factor when comparing smoking attitudes in two states (Ferraro, 1990). Likewise, one of the important influences on parenting practices is accessing sources of support and information (Belsky, 1984). Because parenting attitudes and beliefs are formed in part by the influence of those in one's context and by what one reads (Richardson, Abramowitz, Asp, \& Peterson, 1986), it is useful to examine the spanking advice parents receive and how important they perceive this advice to be.

\section{Research Questions}

Parents need access to a wide range of nonabusive, positive, and effective disciplinary behaviors (Baumrind, 1996). Part of the process of increasing access to information about positive parenting practices is understanding the messages from discipline information sources and their importance to parents. Using the framework of the health belief model, my objectives were to compare spankers and nonspankers on the importance of sources of discipline information, the nature of spanking advice from these sources, and the intensity of messages toward recommending and opposing spanking. The fourth objective was to assess the degree to which the message intensity of recommending or opposing of spanking was associated with the use of spanking.

\section{Method}

\section{Participants}

The data were from a study conducted in two counties in Minnesota by the University of New Hampshire (Straus \& Mouradian, 1998) in 1993 to evaluate the effectiveness of a program to change attitudes and behavior about corporal punishment. The counties are thriving agricultural regions containing small manufacturing- and service-centered cities.

During a 20-minute telephone interview, 998 mothers answered approximately 130 questions about child behavior problems, discipline strategies, discipline information sources, parenting practices, personality, and family issues. Random digit dialing was used to select a sample of mothers of children aged 2 to 14 . If a mother had more than one child in this age range, the child with the most recent birthday was the focus of the interview. Mothers were chosen as the respondents because mothers have more of the day-to-day child-care responsibilities (Milkie, Bianchi, Mattingly, \& Robinson's study as cited in Population Reference Bureau, 2001).

The mothers were primarily from two-parent families $(93.7 \%)$ and from first marriages $(85.0 \%)$. The mean age of the mothers was $37(S D=5.6)$. They had an average of two children living at home. The mean age of the focal child was $8.6(S D=$ $3.7)$, and they were about equally divided between boys $(54 \%)$ and girls $(46 \%)$. Consistent with census data on the socioeconomic composition of these two communities, the sample was almost entirely White, and $48.8 \%$ had at least some college. 


\section{Measures}

Importance of discipline information sources. Questions were asked about how important eight sources of information were in the mother's thinking about discipline: parents and relatives; friends; magazine and newspaper articles; child-rearing books; pediatricians; ministers, priests, or rabbis; psychologists, social workers, or counselors; and parenting workshops. Participants responded to each question on a 4-point scale $(1=$ not at all important, $4=$ very important).

Perception of spanking message. For each of the eight sources of discipline information, participants were asked if that source recommended spanking as a way to discipline. Responses were 1 (recommended,) 2 (neutral,), and 3 (opposed spanking).

Message intensity. Two spanking intensity indexes were created to capture the intensity of the message about spanking. One index was defined as the total number of sources that recommended spanking weighted by the relative importance of each source. If the source recommended spanking, the source was coded 1 and was multiplied by the relative importance of that source (ranging from $1=$ not important to $4=$ very important), and then these values were summed. The other index was defined as the total number of sources that opposed spanking weighted by the relative importance of each source. If the source opposed spanking, the source was coded as 1 and was multiplied by the relative importance of that source (ranging from $1=$ not important to $4=$ very important), and then these values were summed. The potential range of responses for these two indices was 0 to 32 .

Spanking. Participants were asked "How often did you spank, slap, or hit him/her in the past 6 months?" The possible responses ranged from 0 (never) to 6 (more than 20 times). Consistent with other research (Dietz, 2000; Straus, 1994), the responses were recoded to reflect two categories: spankers (those who spanked once or more) and nonspankers (those who did not spank) in the last 6 months. Spanking chronicity was examined to determine whether there was a difference among mothers who did not spank, spanked less than five times, and spanked more than five times. Results did not reveal significant differences between the two classification techniques.

Demographic data. Because mothers who do and do not spank were compared, demographic data are presented separately for spankers and nonspankers. Demographic data included age of mother, age of child, number of children in household, marital status, education level, and household income. The indicators used to create the socioeconomic status score included the mother's last year of school completed, husband's last year of school completed, and household income. Indicators were converted to a $z$ score with equal weighting.

To control for differences of spanking due to a child's age, two subsets of the sample based on the target child's age were used. Spanking prevalence trends show that the likelihood of being hit slowly declines as a child ages, with a drop in spanking at age 9 (Day, Peterson, \& McCracken, 1998; Dietz, 2000; Straus \& Stewart, 1999). Thus, mothers whose child was 2 to 8 years old were defined as the younger child group $(n=478)$ and those with a child 9 to 14 years were defined as the older child group $(n=520)$.

\section{Analysis}

To compare spankers and nonspankers on the importance of information sources and perception of spanking messages, chi- square analyses were performed because the independent variables, importance of information source, and perception of spanking messages were categorical. To compare spankers and nonspankers and the mean scores on message intensity recommending and opposing spanking, a $t$ test was conducted. Because the dependent variable was dichotomized, logistic regression was used to assess the degree to which message intensity either recommending or opposing spanking was associated with use of spanking.

\section{Results}

\section{Spanking Prevalence}

About one third of the mothers (35.6\%) reported they spanked one or more times in the past 6 months. Possible explanations for the low percentage of mothers who reported spanking could be the time referenced; the location of the study, which is generally a low-spanking region (Straus \& Mouradian, 1998); and the fact that parents of older children made up half of the sample. Just over half $(54.6 \%)$ of mothers with younger children and $18.1 \%$ of mothers with older children reported spanking. Consistent with discipline research (Day et al., 1998; Dietz, 2000; Straus \& Stewart, 1999), mothers with younger children were significantly more likely to spank than those with older children, $\chi^{2}(1, N=998)=144.98, p<.001$. In this study, the majority of mothers of 2 - to 5 -year-olds spanked $(58.5 \%$ to $70.8 \%$ ), and about half of mothers of 6- to 7-year-olds spanked (47.4\% to $54.2 \%)$. A minority of mothers of children aged 8 and older spanked (11.1\% to $35.9 \%)$ in the past 6 months.

\section{Demographic Characteristics of Spankers and Nonspankers}

In the younger and older child groups, nonspanking mothers were significantly more likely to be older themselves and to have older children than were spankers (see Table 1). In the older child group, nonspankers had significantly fewer children at home than spankers. In the younger child group, nonspankers had more education than spankers, although there were no significant differences between spankers and nonspankers regarding marital status and income. In the older child group, nonspankers had higher incomes than spankers; there were no significant differences in marital status and mother's education.

\section{Importance of Information Source}

No differences between spankers and nonspankers of younger children were found in the importance of information sources (see Table 2). In this group, more than one third of both spankers and nonspankers rated pediatricians and workshops as very important sources of discipline information. More than 20\% of both spankers and nonspankers rated newspapers or magazines, books, religious leaders, psychologists, and workshops as very important. In contrast, less than $15 \%$ of spankers and nonspankers rated parents and relatives or friends as very important.

In the older child group, more than $25 \%$ of spankers and nonspankers rated pediatricians as very important for discipline information. Both spankers (20.7\%) and nonspankers (16.8\%) also rated newspapers or magazines as very important. Less than $11 \%$ of spankers and nonspankers rated parents and relatives or friends as very important. Two differences between spankers and nonspankers were how psychologists and workshops were rated. Spankers rated psychologists as somewhat (42.3\%) or very 


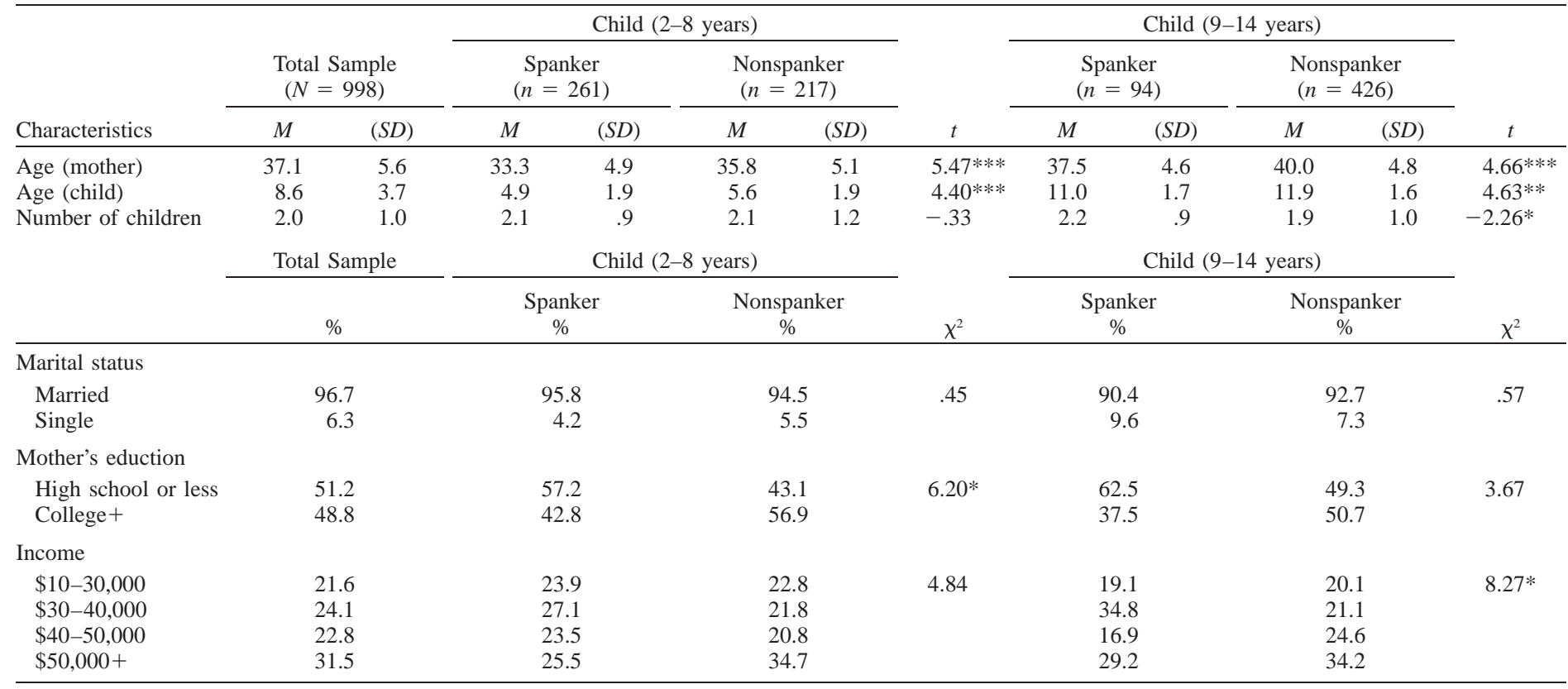

$* p<.05 . * * p<.01 . * * * p<.001$.

(18.3\%) important, whereas $23.2 \%$ and $27.1 \%$ of nonspankers rated psychologists as such. Similarly, spankers were more likely to rate workshops as somewhat $(46.8 \%)$ or very $(23.4 \%)$ important compared with nonspankers $(32.5 \%$ and $32.7 \%$ respectively).

\section{Perception of Spanking Messages}

In the younger child group, spankers and nonspankers perceived receiving significantly different discipline messages from all sources, except psychologists (see Table 3). For example, $55.7 \%$ of spankers and $31.5 \%$ of nonspankers responded that their parents or relatives recommended spanking. Likewise, $43.0 \%$ of spankers and only $16.2 \%$ of nonspankers responded that their friends recommended spanking.

A closer look at the messages perceived by mothers of children aged 2 to 8 years revealed some interesting distinctions between spankers and nonspankers. Messages from pediatricians were perceived differently for spankers and nonspankers. For example, $28.6 \%$ of spankers compared with $45.6 \%$ of nonspankers perceived pediatricians opposing spanking.

In the older child group, spankers and nonspankers perceived significantly different discipline messages from all sources, except newspapers or magazines. About half of spankers $(54.7 \%)$ and $39.5 \%$ of nonspankers perceived their parents or relatives as recommending spanking. Slightly more than one third $(36.0 \%)$ of spankers and $23.2 \%$ of nonspankers viewed their friends as recommending spanking. Similar to the younger child group, $21.7 \%$ of spankers and $41.2 \%$ of nonspankers rated pediatricians as opposing spanking.

In both the younger and older child groups, 30 to 59\% of all the sources were perceived as having neutral messages about spanking. Specifically, pediatricians, religious leaders, and psychologists were most frequently perceived by mothers as neither recommending or opposing spanking. It is impossible to determine the meaning of neutral, however. This response might mean spanking was not addressed, or it might mean that information was equally balanced and parents were encouraged to use their own judgment.

\section{Message Intensity}

In the younger child group, nonspankers had significantly higher scores $(M=8.88, S D=7.45)$ on the Spanking Opposition Intensity Index, which summed the sources opposing spanking relative to their importance, compared with spankers $(M=5.51, S D=6.04), t(476)=5.46, p<.001$. Similarly, spankers had significantly higher scores $(M=4.13, S D=4.59)$ on the Spanking Recommendation Intensity Index, which summed the sources recommending spanking relative to their importance, compared with nonspankers $(M=1.68, S D=2.74)$, $t(476)=-6.92, p<.001$.

Likewise, in the older child group, nonspankers had significantly higher scores $(M=7.72, S D=7.19)$ on the Spanking Opposition Intensity Index compared with spankers $(M=4.55$, $S D=5.12), t(518)=4.04, p<.001$. Similarly, spankers had significantly higher scores $(M=4.10, S D=5.12)$ on the Spanking Recommendation Intensity Index compared with nonspankers $(M=2.24, S D=3.41), t(518)=-4.30, p<.001$.

\section{Predicted Probability of Spanking}

Another objective of this research was to examine the degree to which message intensity was associated with use of spanking. The results of the logistic regression indicated that child's age, socioeconomic status, and both indices of spanking message intensity were all significant predictors of spanking (see Table 4). The odds ratio for child's age (.74) suggests that each additional year of the child's age decreases the likelihood of spanking by $16 \%$. Similarly, the odds ratio of .78 for socioeconomic status (SES) suggests that each increase in SES decreases the likelihood of spanking by $12 \%$. In addition, for each increase in message intensity opposing spanking, there is a decreased likelihood of spanking by $5 \%$ (odds ratio $=.95$ ). Finally, the odds ratio of 1.12 suggests that for each increase in message intensity rec- 


\begin{tabular}{|c|c|c|c|c|c|c|c|}
\hline \multirow[b]{2}{*}{$\begin{array}{l}\text { Information Source: } \\
\text { Importance }\end{array}$} & \multirow[b]{2}{*}{$\begin{array}{l}\text { Total Sample } \\
(N=998)\end{array}$} & \multicolumn{2}{|c|}{ Child (2-8 years) } & \multirow[b]{2}{*}{$\chi^{2}$} & \multicolumn{2}{|c|}{ Child (9-14 years) } & \multirow[b]{2}{*}{$\chi^{2}$} \\
\hline & & $\begin{array}{c}\text { Spanker } \\
(n=261)\end{array}$ & $\begin{array}{l}\text { Nonspanker } \\
(n=217)\end{array}$ & & $\begin{array}{l}\text { Spanker } \\
(n=94)\end{array}$ & $\begin{array}{l}\text { Nonspanker } \\
(n=426)\end{array}$ & \\
\hline \multicolumn{8}{|l|}{ Parents, relatives } \\
\hline $\begin{array}{l}\text { Not important } \\
\text { Slightly important } \\
\text { Somewhat important } \\
\text { Very important }\end{array}$ & $\begin{array}{l}33.8 \\
30.0 \\
24.6 \\
11.5\end{array}$ & $\begin{array}{l}29.4 \\
30.6 \\
25.5 \\
14.5\end{array}$ & $\begin{array}{l}34.9 \\
29.8 \\
23.7 \\
11.6\end{array}$ & 2.00 & $\begin{array}{r}31.9 \\
38.3 \\
24.5 \\
5.3\end{array}$ & $\begin{array}{l}36.4 \\
28.0 \\
24.6 \\
11.0\end{array}$ & 5.65 \\
\hline \multicolumn{8}{|l|}{ Friends } \\
\hline $\begin{array}{l}\text { Not important } \\
\text { Slightly important } \\
\text { Somewhat important } \\
\text { Very important }\end{array}$ & $\begin{array}{r}32.5 \\
29.1 \\
29.7 \\
8.7\end{array}$ & $\begin{array}{r}32.2 \\
27.5 \\
33.3 \\
7.0\end{array}$ & $\begin{array}{l}30.7 \\
29.3 \\
29.3 \\
10.7\end{array}$ & 2.69 & $\begin{array}{l}29.0 \\
23.7 \\
36.6 \\
10.8\end{array}$ & $\begin{array}{r}34.4 \\
31.1 \\
26.1 \\
8.3\end{array}$ & 5.57 \\
\hline \multicolumn{8}{|l|}{ Newspaper/magazine } \\
\hline $\begin{array}{l}\text { Not important } \\
\text { Slightly important } \\
\text { Somewhat important } \\
\text { Very important }\end{array}$ & $\begin{array}{l}13.3 \\
23.4 \\
43.6 \\
19.8\end{array}$ & $\begin{array}{l}12.5 \\
20.6 \\
44.4 \\
22.6\end{array}$ & $\begin{array}{r}9.8 \\
21.5 \\
46.7 \\
22.0\end{array}$ & .93 & $\begin{array}{l}14.1 \\
27.2 \\
38.0 \\
20.7\end{array}$ & $\begin{array}{l}15.4 \\
25.1 \\
42.7 \\
16.8\end{array}$ & 1.22 \\
\hline \multicolumn{8}{|l|}{ Books } \\
\hline $\begin{array}{l}\text { Not important } \\
\text { Slightly important } \\
\text { Somewhat important } \\
\text { Very important }\end{array}$ & $\begin{array}{l}16.1 \\
22.9 \\
39.6 \\
21.4\end{array}$ & $\begin{array}{l}16.7 \\
20.7 \\
41.5 \\
21.1\end{array}$ & $\begin{array}{l}10.4 \\
22.3 \\
41.1 \\
26.2\end{array}$ & 4.51 & $\begin{array}{l}13.5 \\
27.0 \\
34.8 \\
24.7\end{array}$ & $\begin{array}{l}19.2 \\
23.6 \\
38.7 \\
18.5\end{array}$ & 3.39 \\
\hline \multicolumn{8}{|l|}{ Pediatricians } \\
\hline $\begin{array}{l}\text { Not important } \\
\text { Slightly important } \\
\text { Somewhat important } \\
\text { Very important }\end{array}$ & $\begin{array}{l}22.6 \\
14.0 \\
31.8 \\
31.6\end{array}$ & $\begin{array}{l}19.1 \\
10.9 \\
32.6 \\
37.4\end{array}$ & $\begin{array}{l}23.1 \\
14.4 \\
28.7 \\
33.8\end{array}$ & 2.70 & $\begin{array}{l}13.5 \\
15.7 \\
37.1 \\
33.7\end{array}$ & $\begin{array}{l}26.7 \\
15.4 \\
31.5 \\
26.4\end{array}$ & 7.24 \\
\hline \multicolumn{8}{|l|}{ Minister, priest, rabbi } \\
\hline $\begin{array}{l}\text { Not important } \\
\text { Slightly important } \\
\text { Somewhat important } \\
\text { Very important }\end{array}$ & $\begin{array}{l}36.2 \\
14.3 \\
26.8 \\
22.7\end{array}$ & $\begin{array}{l}32.0 \\
16.2 \\
28.1 \\
23.7\end{array}$ & $\begin{array}{l}40.6 \\
12.8 \\
23.5 \\
23.0\end{array}$ & 3.77 & $\begin{array}{l}26.8 \\
12.2 \\
36.6 \\
24.4\end{array}$ & $\begin{array}{l}38.5 \\
14.3 \\
25.6 \\
21.6\end{array}$ & 5.92 \\
\hline \multicolumn{8}{|l|}{ Psychologist } \\
\hline $\begin{array}{l}\text { Not important } \\
\text { Slightly important } \\
\text { Somewhat important } \\
\text { Very important }\end{array}$ & $\begin{array}{l}33.1 \\
14.2 \\
26.0 \\
26.7\end{array}$ & $\begin{array}{l}34.6 \\
10.3 \\
25.4 \\
29.7\end{array}$ & $\begin{array}{l}31.2 \\
17.2 \\
25.5 \\
26.1\end{array}$ & 3.72 & $\begin{array}{l}25.4 \\
14.1 \\
42.3 \\
18.3\end{array}$ & $\begin{array}{l}34.8 \\
14.9 \\
23.2 \\
27.1\end{array}$ & $11.37 * *$ \\
\hline \multicolumn{8}{|l|}{ Workshop } \\
\hline $\begin{array}{l}\text { Not important } \\
\text { Slightly important } \\
\text { Somewhat important } \\
\text { Very important }\end{array}$ & $\begin{array}{l}19.7 \\
11.2 \\
35.7 \\
33.5\end{array}$ & $\begin{array}{l}14.7 \\
11.9 \\
39.4 \\
33.9\end{array}$ & $\begin{array}{l}18.2 \\
10.8 \\
32.4 \\
38.6\end{array}$ & 2.78 & $\begin{array}{r}24.7 \\
5.2 \\
46.8 \\
23.4\end{array}$ & $\begin{array}{l}22.5 \\
12.3 \\
32.5 \\
32.7\end{array}$ & $8.44^{*}$ \\
\hline
\end{tabular}

$* p<.05 . * * p<.01$.

ommending spanking there is a $12 \%$ increased likelihood of spanking.

\section{Discussion}

Because parenting attitudes and beliefs are formed in part by the influence of those around us and also by what we read (Richardson et al., 1986) and because few studies have investigated which parenting resources are perceived most helpful by parents (Thompson, 1994), I examined the advice mothers receive about the appropriateness of spanking and the perceived importance of these information sources. Using the health belief model (Ferraro, 1990), spankers and nonspankers were compared on the importance of and spanking message received from eight sources of discipline information. I also compared spankers and nonspankers on the spanking message intensity and assessed the degree to which spanking message intensity was associated with reported use of spanking.

\section{Importance and Spanking Message of Information Source}

Spankers and nonspankers with both younger and older children rated the importance of discipline information sources similarly. Discipline advice from workshops, pediatricians, newspapers and magazines, and books was rated by more mothers as at least somewhat important. In contrast, informal sources, such as parents and relatives or friends, were rated by more mothers as not important or slightly important. This is consistent with other research (Clarke-Stewart, 1978; Riley et al., 1991; Stolz, 1967) that found professional people, parenting books, and newsletters were influential sources on parenting in general.

Perhaps parents, relatives, and friends were perceived as less important sources because mothers want to feel independent about how they discipline their children, dislike these models in general, or disagree with the advice. Mothers may value disci- 
Mothers' Perceptions of Spanking Message by Information Source in Percent

\begin{tabular}{|c|c|c|c|c|c|c|c|}
\hline \multirow[b]{2}{*}{$\begin{array}{l}\text { Information Source: } \\
\text { Message }\end{array}$} & \multirow[b]{2}{*}{$\begin{array}{l}\text { Total Sample } \\
(N=998)\end{array}$} & \multicolumn{2}{|c|}{ Child (2-8 years) } & \multirow[b]{2}{*}{$\chi^{2}$} & \multicolumn{2}{|c|}{ Child (9-14 years) } & \multirow[b]{2}{*}{$\chi^{2}$} \\
\hline & & $\begin{array}{c}\text { Spanker } \\
(n=261)\end{array}$ & $\begin{array}{l}\text { Nonspanker } \\
(n=217)\end{array}$ & & $\begin{array}{l}\text { Spanker } \\
(n=94)\end{array}$ & $\begin{array}{l}\text { Nonspanker } \\
(n=426)\end{array}$ & \\
\hline \multicolumn{8}{|l|}{ Parents, relatives } \\
\hline $\begin{array}{l}\text { Recommend } \\
\text { Neutral } \\
\text { Oppose }\end{array}$ & $\begin{array}{l}43.3 \\
38.5 \\
18.2\end{array}$ & $\begin{array}{l}55.7 \\
33.3 \\
11.0\end{array}$ & $\begin{array}{l}31.5 \\
46.0 \\
22.5\end{array}$ & $29.57 * * *$ & $\begin{array}{l}54.7 \\
33.7 \\
11.6\end{array}$ & $\begin{array}{l}39.5 \\
38.7 \\
21.8\end{array}$ & $8.04 *$ \\
\hline \multicolumn{8}{|l|}{ Friends } \\
\hline $\begin{array}{l}\text { Recommend } \\
\text { Neutral } \\
\text { Oppose }\end{array}$ & $\begin{array}{l}28.1 \\
43.6 \\
28.2\end{array}$ & $\begin{array}{l}43.0 \\
42.6 \\
14.5\end{array}$ & $\begin{array}{l}16.2 \\
45.6 \\
38.2\end{array}$ & $51.47 * * *$ & $\begin{array}{l}36.0 \\
50.0 \\
14.0\end{array}$ & $\begin{array}{l}23.2 \\
41.9 \\
34.8\end{array}$ & $15.52^{* * * *}$ \\
\hline \multicolumn{8}{|l|}{ Newspaper/magazine } \\
\hline $\begin{array}{l}\text { Recommend } \\
\text { Neutral } \\
\text { Oppose }\end{array}$ & $\begin{array}{l}13.3 \\
32.5 \\
54.3\end{array}$ & $\begin{array}{l}18.8 \\
32.9 \\
48.3\end{array}$ & $\begin{array}{r}8.4 \\
30.3 \\
61.6\end{array}$ & $12.29 * *$ & $\begin{array}{l}14.5 \\
41.0 \\
44.6\end{array}$ & $\begin{array}{l}12.2 \\
31.6 \\
56.2\end{array}$ & 3.79 \\
\hline \multicolumn{8}{|l|}{ Books } \\
\hline $\begin{array}{l}\text { Recommend } \\
\text { Neutral } \\
\text { Oppose }\end{array}$ & $\begin{array}{l}17.5 \\
30.6 \\
51.9\end{array}$ & $\begin{array}{l}24.5 \\
31.9 \\
43.5\end{array}$ & $\begin{array}{l}11.4 \\
30.3 \\
58.4\end{array}$ & $13.85^{* * * *}$ & $\begin{array}{l}31.3 \\
38.8 \\
30.0\end{array}$ & $\begin{array}{l}13.4 \\
28.1 \\
58.5\end{array}$ & $25.00 * * *$ \\
\hline \multicolumn{8}{|l|}{ Pediatricians } \\
\hline $\begin{array}{l}\text { Recommend } \\
\text { Neutral } \\
\text { Oppose }\end{array}$ & $\begin{array}{r}4.4 \\
58.7 \\
36.9\end{array}$ & $\begin{array}{r}6.5 \\
64.9 \\
28.6\end{array}$ & $\begin{array}{c}0 \\
54.5 \\
45.6\end{array}$ & $18.72 * * *$ & $\begin{array}{l}13.0 \\
65.2 \\
21.7\end{array}$ & $\begin{array}{r}3.3 \\
55.5 \\
41.2\end{array}$ & $16.37 * * *$ \\
\hline \multicolumn{8}{|l|}{ Minister, priest, rabbi } \\
\hline $\begin{array}{l}\text { Recommend } \\
\text { Neutral } \\
\text { Oppose }\end{array}$ & $\begin{array}{l}11.1 \\
56.9 \\
32.0\end{array}$ & $\begin{array}{l}15.1 \\
62.2 \\
22.7\end{array}$ & $\begin{array}{r}4.7 \\
56.1 \\
39.2\end{array}$ & $15.98 * * *$ & $\begin{array}{l}21.4 \\
62.9 \\
15.7\end{array}$ & $\begin{array}{r}9.5 \\
52.9 \\
37.9\end{array}$ & $16.00 * * *$ \\
\hline \multicolumn{8}{|l|}{ Psychologist } \\
\hline $\begin{array}{l}\text { Recommend } \\
\text { Neutral } \\
\text { Oppose }\end{array}$ & $\begin{array}{r}5.1 \\
49.6 \\
45.3\end{array}$ & $\begin{array}{r}8.7 \\
54.8 \\
36.5\end{array}$ & $\begin{array}{r}4.1 \\
49.6 \\
46.3\end{array}$ & 3.76 & $\begin{array}{r}5.3 \\
61.4 \\
33.3\end{array}$ & $\begin{array}{r}3.7 \\
44.3 \\
52.0\end{array}$ & $6.48 *$ \\
\hline \multicolumn{8}{|l|}{ Workshop } \\
\hline $\begin{array}{l}\text { Recommend } \\
\text { Neutral } \\
\text { Oppose }\end{array}$ & $\begin{array}{r}6.0 \\
41.2 \\
52.8\end{array}$ & $\begin{array}{r}9.8 \\
47.1 \\
43.1\end{array}$ & $\begin{array}{r}5.3 \\
31.8 \\
62.9\end{array}$ & $12.92 * *$ & $\begin{array}{r}8.3 \\
60.0 \\
31.7\end{array}$ & $\begin{array}{r}3.6 \\
38.5 \\
57.9\end{array}$ & $14.28 * * *$ \\
\hline
\end{tabular}

${ }^{*} p<.05 .{ }^{* *} p<.01 . * * * p<.001$.

Table 4

Spanking Message Intensity and Spanking Behavior ( $\mathrm{N}=998)$

\begin{tabular}{lccc}
\hline Predictors of Spanking & $B$ & $S E$ & Odds Ratio \\
\hline Child's age & -.31 & .09 & $.74 * * *$ \\
Socioeconomic status & -.24 & .09 & $.78^{* *}$ \\
Opposition intensity & -.05 & .01 & $.95 * * *$ \\
Recommendation intensity & .12 & .02 & $1.12^{* * *}$
\end{tabular}

$* * p<.01 . * * * p<.001$.

pline advice from sources that they perceive as more objective and expert than advice from family and friends. For example, Riley et al. (1991) found mothers rated a parenting newsletter as "very useful" more often than any other source, including relatives and friends. It also is possible that mothers incorporate advice from their own parents without explicitly recognizing it. If this holds true, then the mothers in this sample may draw from their own experience of being parented (Edwards, 1995).

Spankers and nonspankers perceived different messages about the appropriateness of spanking. Spankers perceived sources as recommending spanking, whereas nonspankers perceived these sources as opposed to spanking. These results may be interpreted several ways. For example, because a family's environment is a source of child-rearing ideas (Powell, 1979), perhaps the social networks of mothers who do and do not spank provide different messages about spanking. Another explanation could be that mothers perceive discipline messages as reaffirming their own parenting practices, such that they tend to hear and remember information that matches what they already do or believe. This idea would lend support to the "specificity hypothesis," which contends that when faced with a particular problem, individuals will seek others with similar experiences as sources of support (Suitor, Pillemer, \& Keeton, 1995). Extending this research to the present findings, it would seem likely that parents associate with people who may hold the same beliefs, such as beliefs about discipline techniques.

In contrast to the specificity hypothesis, the health belief model (Mikanowicz, Fitzgerald, Leslie, \& Altman, 1999) suggests that cues in one's environment affect behavior. Perceived community and cultural norms often influence an individual's behavior. For example, educational messages and mothers' perception of the community's social norms about the health benefits of breast-feeding were important considerations in mothers' infant feeding decisions (Guttman \& Zimmerman, 2000). Likewise, perceived messages about spanking may affect mothers' discipline decisions. Without longitudinal data, however, it is not possible to determine explicitly whether such messages influence discipline actions or visa versa.

Although there were differences in spankers' and nonspank- 
ers' perceptions of spanking messages, there also were similarities. At least $30 \%$ of both groups perceived messages from newspapers and magazines, books, psychologists, and workshops as opposing spanking. Given that so many mothers perceive a fairly large percentage of sources as opposing spanking, it is curious that these mothers still spank. It may be that Belsky's (1984) process parenting model, indicating that there are a number of influences on how information is incorporated, is applicable here. According to Belsky, for example, the personal characteristics of the parent are one of the most influential factors for competent parenting. Therefore, perhaps it is the combination of perceiving messages opposed to spanking and parents' personal characteristics, such as readiness to incorporate information into their behavior, that is critical to consider when examining the association of messages and behavior.

\section{Message Intensity}

In addition to having different perceptions about the appropriateness of spanking, spankers and nonspankers also had different spanking message intensities. Spankers scored higher than nonspankers on the index that summed the sources recommending spanking relative to the importance of the sources. Similarly, nonspankers scored higher on the index that summed the sources opposing spanking relative to the importance of the sources. These results reinforce the association between information and child-rearing ideas (Tracy, 1990; McKenry, Kotch, \& Browne, 1991).

Spankers had similar scores on both the recommendation and opposition indexes, whereas nonspankers had more messages that opposed spanking. In addition, increases in the recommendation index were associated with increases in the odds of spanking, whereas increases in the opposition index were associated with decreases in the odds of spanking. It may be that mothers need to perceive many more messages that oppose spanking to experience a substantial reduction in spanking. Thus, these findings are consistent with the health belief model, suggesting that perceptions of what is appropriate behavior are associated with behavior.

\section{Limitations}

A number of limitations of this research are noted. First, because these are cross-sectional data, it is impossible to establish any causal direction. It cannot be said that spanking messages result in the use of spanking because it also may be that use of spanking results in greater attention to certain spanking messages. Another limitation is that the data are from mothers only. Future research should gather information from all caretakers to better understand the family context of information sharing and discipline action. Additionally, because the time frame for recall was the past 6 months, mothers might have forgotten how often they spanked.

Another issue is the way in which mothers were classified as spankers or nonspankers, resulting in the potential for misclassification. For example, although nonspankers responded that they did not spank the target child during the past 6 months, these mothers may have spanked at some point or may have spanked another child, so the estimate of the number of mothers who actually spank may be conservative. In addition, because of social desirability to underreport, these are lower bound estimates. Finally, because the sample was primarily White and from two Midwestern cities, the findings are not generalizable. Spanking attitudes and behavior vary by geographic location and ethnicity (Dietz, 2000; Giles-Sims et al., 1995; Straus \& Mathur, 1996).

\section{Implications for Parent Education Programs}

The findings shed some light on mothers' perceptions of sources and importance of discipline advice and suggest concrete ways to provide information to mothers. Mothers valued discipline advice from parenting courses or workshops, pediatricians, newspaper and magazine articles, and parenting books. As such, parenting information can be fairly easily disseminated to a wide audience, and the majority of those reading it would see it as valuable. This implies that those responsible for parenting workshops and those who write for the popular press have the potential to educate parents about alternatives to spanking.

These findings reaffirm the benefits of publishing articles about positive parenting practices and suggest that initiating a community public awareness campaign about alternatives to spanking would be valuable. In addition, it may be beneficial to target efforts to provide research-based discipline information to parents of young children and those parents with limited education.

These results also highlight another important area. It may be beneficial to give such discipline information not only to parents, but also to other professionals in the community. For example, parent educators could send pediatricians, religious leaders, and psychologists research-based information for dissemination. Because $50 \%$ to $59 \%$ of mothers perceived these professionals as neither recommending nor opposing spanking, these professionals might benefit by having such information.

Pediatricians, in particular, could play an important role in dissemination efforts. For example, $63 \%$ of mothers perceived pediatricians as somewhat or very important information sources; yet only $37 \%$ of mothers perceived that pediatricians opposed spanking. These results suggest that pediatricians' role in distributing information about discipline should be enhanced. For example, in addition to giving parents printed material, pediatricians could discuss child discipline and link parents to parenting resources in their community. Pediatricians may be an underdeveloped and valuable resource for educating parents about alternatives to spanking that is easily accessible to parents.

\section{Conclusion}

This research contributes to the knowledge illustrating how child-rearing ideas from many sources are associated with behavior. This study also adds to our understanding of how mothers perceive discipline messages. By increasing our understanding of what information sources are important, we can develop ways to make positive discipline approaches more accessible to parents.

\section{References}

Barber, J. G. (1992). Evaluating parent education groups: Effects on sense of competence and social isolation. Research on Social Work Practice, 2, 28 38.

Baumrind, D. (1996). The discipline controversy revisited. Family Relations, 45, 405-414.

Belsky, J. (1984). The determinants of parenting: A process model. Child Development, 55, 83-96.

Bryan, J. W., \& Freed, F. W. (1982). Corporal punishment: Normative data and sociological and psychological correlates in a community college population. Journal of Youth and Adolescence, 11, 77-87.

Clarke-Stewart, K. A. (1978). Popular primers for parents. American Psychologist, 33, 359-369. 
Daro, D., \& Gelles, R. J. (1992). Public attitudes and behaviors with respect to child abuse prevention. Journal of Interpersonal Violence, 7, 517-531.

Day, R. D., Peterson, G. W., \& McCracken, C. (1998). Predicting spanking of younger and older children by mothers and fathers. Journal of Marriage and the Family, 60, 79-94.

Deater-Deckard, K., Dodge, K. A., Bates, J. E., \& Pettit, J. E. (1996). Physical discipline among African American and European American mothers: Links to children's externalizing behaviors. Developmental Psychology, 32, 10651072.

Dietz, T. L. (2000). Disciplining children: Characteristics associated with the use of corporal punishment. Child Abuse and Neglect, 24, 1529-1542.

Edwards, J. (1995). "Parenting skills": Views of community health and social service providers about the needs of their "clients". Journal of Social Policy, 24, 237-259.

Ferraro, K. F. (1990). Health beliefs and proscriptions on public smoking. Sociological Inquiry, 60, 244-263.

Foglia, W. D. (1997). Perceptual deterrence and the mediating effect of internalized norms among inner-city teenagers. Journal of Research in Crime and Delinquency, 34, 414-442.

Giles-Sims, J., Straus, M. A., \& Sugarman, D. B. (1995). Child, maternal, and family characteristics associated with spanking. Family Relations, 44, 170176.

Graziano, A. M., \& Namaste, K. A., (1990). Parental use of physical force in child discipline. Journal of Interpersonal Violence, 5, 449-463.

Greven, P. (1991). Spare the child: The religious roots of punishment and the psychological impact of physical punishment. New York: Knopf.

Grusec, J. E., \& Goodnow, J. J. (1994). Impact of parental discipline methods on the child's internalization of values: A reconceptualization of current points of view. Developmental Psychology, 30, 4-19.

Guttman, N., \& Zimmerman, D. R. (2000). Low-income mothers' views on breastfeeding. Social Science and Medicine, 50, 1457-1473.

Holden, G. W., \& Ritchie, K. L. (1991). Linking extreme marital discord, child rearing, and child behavior problems: Evidence from battered women. Child Development, 62, 311-327.

Kadushin, A., \& Martin, J. A. (1981). Child abuse: An interactional event. New York: Columbia University Press.

Larzelere, R. (1996). Implications of the strongest studies for discriminating effective vs. counterproductive corporal punishment. Pediatrics, 98, 824-828.

McCord, J. (1991). Questioning the value of punishment. Social Problems, 38, $167-179$.

McCord, J. (1996). Unintended consequences of punishment. Pediatrics, 98, 832-834.

McKenry, P. C., Kotch, J. B., \& Browne, D. H. (1991). Correlates of dysfunctional parenting attitudes among low-income adolescent mothers. Journal of Adolescent Research, 6, 212-234.

Mikanowicz, C. K., Fitzgerald, D. C., Leslie, M., \& Altman, N. H. (1999). Medium-sized business employees speak out about smoking. Journal of Community Health, 24, 439-450.

Oldershaw, L., Walters, G. C., \& Hall, D. K. (1989). A behavioral approach to the classification of different types of physically abusive mothers. Merrill Palmer Quarterly, 35, 255-279.

Patterson, G. R., \& Narrett, C. M. (1990). The development of a reliable and valid treatment program for aggressive young children. International Journal of Mental Health, 19, 19-26.

Population Reference Bureau. (2001). American families resilient after 50 years of change. Washington, DC: Author.

Portnoy, B., Anderson, D. M., \& Erikson, M. P. (1989). Application of diffusion theory to health promotion research. Family and Community Health, 12, 6371.

Powell, D. R. (1979). Family-environment relations and early childrearing: The role of social networks and neighborhoods. Journal of Research and Development in Education, 13, 1-11.

Richardson, R. A., Abramowitz, R. H., Asp, C. E., \& Peterson, A. C. (1986) Parent-child relationships in early adolescence: Effects of family structure. Journal of Marriage and the Family, 48, 805-811.

Riley, D., Meinhardt, G., Nelson, C., Salisbury, M. J., \& Winnett, T. (1991). How effective are age-paced newsletters for new parents? A replication and extension of earlier studies. Family Relations, 40, 247-253.

Rodriquez, C. M., \& Sutherland, D. (1999). Predictors of parents' physical disciplinary practices. Child Abuse \& Neglect, 23, 651-657.

Small, S. A., \& Eastman, G. (1991). Rearing adolescents in contemporary society: A conceptual framework for understanding the responsibilities and needs of parents. Family Relations, 40, 455-462.

Stolz, L. M. (1967). Influences on parent behavior. Stanford, CA: Stanford University Press.

Strassberg, Z., Dogde, K. A, Pettit, G. S., \& Bates, J. E. (1994). Spanking in the home and children's subsequent aggression toward kindergarten peers. Development and Psychopathology, 6, 445-461.

Straus, M. A. (1994). Beating the devil out of them: Corporal punishment by parents and its effects on children. Boston: Lexington/Macmillian.

Straus, M. A., \& Mathur, A. (1996). Social change and change in approval of corporal punishment by parents from 1968 to 1994. In D. Frehsee, W. Horn, \& K. D. Bussmann (Eds.), Family violence against children: A challenge for society (pp. 91-105). New York: de Gruyter.

Straus, M. A., \& Mouradian, V. E. (1998). Impulsive corporal punishment by mothers and antisocial behavior and impulsiveness of children. Behavioral Sciences and the Law, 16, 353-374.

Straus, M. A., \& Stewart, J. H. (1999). Corporal punishment by American parents: National data on prevalence, chronicity, severity, and duration, in relation to child, and family characteristics. Clinical Child and Family Psychology Review, 2, 55-70.

Straus, A., Sugarman, D., \& Giles-Sims, J. (1997). Spanking by parents and subsequent antisocial behavior of children. Journal of Pediatrics and Adolescent Medicine, 151, 761-767.

Suitor, J. J., Pillemer, K., \& Keeton, S. (1995). When experience counts: The effects of experiential and structural similarity on patterns of support and interpersonal stress. Social Forces, 73, 1573-1588.

Swinford, S. P., DeMaris, A., Cernkovick, S. A., \& Giordano, P. C. (2000). Harsh physical discipline in childhood and violence in later romantic involvements: The mediating role of problem behaviors. Journal of Marriage and the Family, $62,508-519$.

Thompson, R. A. (1994). Social support and the prevention of child maltreatment. In G. B. Melton \& F. D. Barry (Eds.), Protecting children from abuse and neglect foundations for a new national strategy (pp. 40-130). New York: Guilford Press.

Tracy, E. M. (1990). Identifying social support resources of at-risk families. Social Work, 35, 252-258.

Whipple, E. E., \& Richey, C. A. (1997). Crossing the line from physical discipline to child abuse: How much is too much? Child Abuse and Neglect, 21, 431-444.

Whipple, E. E., \& Webster-Stratton, C. (1991). The role of parental stress in physically abusive families. Child Abuse and Neglect, 15, 279-291.

Wolfner, G. D., \& Gelles, R. J. (1993). A profile of violence toward children: A national study. Child Abuse and Neglect, 17, 197-212.

Young, K. T., Davis, K., \& Schoen, C. (1996). The Commonwealth Fund survey of parents with young children. New York: Commonwealth Fund. 